\title{
8 \\ Japan in engagement and the discourses of civilisation
}

If civilisational analysis is lacking with respect to Latin America, it has been far from inattentive when it comes to Japan. In previous chapters, Japan serves as an illustration of theoretical engagements with civilisational analysis, as well as illustrating different points of my own argument. The frequent choice of Japan is no coincidence: it has been a focal point of investigation for comparativists in the humanities, the social sciences and political economy with an interest in civilisations. When it comes to the specific field of contemporary civilisational analysis, Arnason, Robert Bellah and Eisenstadt have produced in-depth monographs and numerous essays on Japanese civilisation (Arnason, 1997a, 2002; Bellah, 2003; Eisenstadt, 1996, 2002a). A few others could be mentioned as interlocutors between Japanese Studies as a field and civilisational analysis: Praesenjit Duara (as we shall see), Roland Robertson, Yoshio Sugimoto and Tadao Umesao.

This chapter begins with a brief assessment of the results of the three historical sociologies crafted in the tradition of civilisational analysis. I then move to explore a key phase of Japanese civilisation's interactions. My strategy involves pushing the notions of inter-civilisational interactions and encounters at work in Arnason, Bellah and Eisenstadt further by examining how deeper connections have influenced the coalescence of modern cultural and political thought. The phase I examine begins in the early Meiji period (1868-1912) and ends in the 1920s. Echoing Duara's analysis of East Asia, I submit that a 'discourse of civilisations' formed in Japan through intensive experience of engagement with the West and other countries. Japan's multiple engagements occurred in specific contexts of cultural transactions across what were defined - though ultimately contingent - civilisational boundaries. My focus is on contested conceptions of 'civilisation' thrown up by inter-civilisational engagement in East Asia. 


\section{Japan in focus}

To varying degrees, the three major perspectives on Japan in contemporary civilisational analysis stress the long-term impulses of development. With the following points I will attempt to summarise what Arnason, Bellah and Eisenstadt are agreed on. Japan's civilisational animus formed in the course of historical experiences in East Asia. A critical juncture was reached in the seventh century, when the Taika Reforms were adopted. Reform of the structures of state, the conduct of government and the figuration of court and provincial powers consolidated Japan's imperial sovereignty over two centuries. The collective experience of adoption and reconstruction of outside models was the common element of all the reforms introduced from China. A generic pattern emerged in this long learning experience whereby the originally emulated elements of Confucian state culture were transformed into Japanese cultural and political traditions. Relations with East Asia at large conditioned developmental patterns from the Heian era onwards (798-1185), inasmuch as orientations to the Sinic world order always structured the organisation of power, changing techniques of statecraft and philosophical and religious doctrine. China's presence in the cultural, religious and economic universes of Japanese civilisation lent the latter a dual character. That Japan's relational orientation is reaffirmed throughout its history is evident in major episodes of engagement with the outside world and reflection on its existing dynamic traditions.

The formative period features in the three major perspectives. The three diverge, however, on how social change is conditioned by relations with the East Asian region. For Eisenstadt, Japan was an unusual de-axialising civilisation (1996). In its digestion and relativisation of the world religions, Japan had a foundational moment in which a pattern of ontological dualism was established. The universalism of philosophy and religions entering from Asia was relativised when resituated in Japanese cultural environments. Native traditions played off against foreign influences during the early era of adaptation of the Chinese model set an ontological blueprint of uchi-soto (inside-outside) orientations for relations with foreign cultures. Uchi-soto demanded highly creative agency on part of the intelligentsia. In that role, intellectuals reinterpreted the polarised dualisms of the doctrines of Buddhism and Confucianism and diminished the polarity of opposites. In doing so, they produced different versions of situational ethics. From the ontological principles of imported relations, they selected only those elements that were given to easy accommodation of varying environments. In rejecting stronger axioms, Japanese civilisation adopted a trajectory of negation of universalist principles. 
Arnason's reconstruction of the historical experiences diverges from Eisenstadt's on key points (1997a). Though there are similarities in how each views the ontological shape of Japanese dualism, Arnason baulks at the linear trajectory implicit in Eisenstadt's application of the theory of Axial civilisations to a comparative sociology of Japan. Arnason views the original Japanese constellation as a mixture of archaic and foreign elements that is too messy to subsume under the categories of Axial civilisations, or to account for as a process of deaxialisation. The originality of historical experiences cannot simply be accounted for by means of a far-reaching qualification of Axial traditions that Eisenstadt strives for. Instead, Arnason perceives greater space for interpretation, reconstruction and reinterpretation of civilisational dynamics in the centres of power. Strategic orientations have a more decisive part and thus Arnason attributes more historical specificity to processes of change, including in modernity. Arnason's rendition of the Japanese trajectory asserts more latitude for transformative processes to be analysed. Furthermore, there is greater room for the ramifications of transformation for the overall pattern of duality to be taken into account.

Like Eisenstadt, Bellah conceives of Japanese civilisation as non-Axial. His early research anticipated Eisenstadt's judgement that Japan de-axialised foreign doctrines and religions (Bellah, 2003: 4). In defining historical periods, cultural elites sought to introduce transcendental doctrines and religious ethics into Japanese society, only to find that 'the moment of transcendence was quickly submerged' (2003: 4). The most important outside influences were religious, for Bellah as a neo-Weberian at least. The submergence of transcendence did not entail its abandonment, however, but an appreciation of foreign cultures contextualised by Japan's own non-Axial premises. The major transcendental movements - the world religions and Marxism - find a place in society, but have negligible impact on the core ethics of Japanese culture. They coexist with native beliefs and have many followers, but do so in a submerged state.

There is a clear resemblance to Eisenstadt's perspective. Bellah diverges on one crucial point: Japanese civilisation is pre-Axial inasmuch as its premises are deep-seated and unmovable. 'They are off the board ... when it comes to serious discussion of fundamental change' (Bellah, 2003: 6). There is an image of cultural segmentation produced in Bellah's description of Japan's engagement with the universalist premises of the world religions. I suggest, instead, that international movements, currents of belief and thought and political models had more subtle and sustained effects on Japanese culture. A highly relational society emerged and not just a segmented social order of coexisting groups. I prosecute an argument along these lines below by exploring the modern intelligentsia of the Meiji era and their struggles and achievements. 
Still, there is more to Bellah's penetrating analysis. China was the luminous centre of the East Asian order with deep influence on other polities in the region and their figurations of power. In Japan, patterns of military rule both emulated and diverged from the Sinic constellation of East Asia. The revolutionary restoration of the Meiji era transformed the state, structures of the public sphere and social relations. The magnitude of change did not fundamentally displace non-Axial principles, according to Bellah, which remained evident in the form of nationalism that emerged. Even in modernity, Japan's non-Axial principles are still primary in rooting the social and political order in the particularism of Japanese civilisation (Bellah, 2003: 39). In this aspect of Bellah's argument, he is closer to Eisenstadt than Arnason in emphasising the enduring longevity of the civilisational premises of this particular East Asian trajectory. Consistent with Weberian principles, universalist cosmologies are central to the problems under consideration and historical questions are posed in frames of long-term history.

No more systematic assessment of the three perspectives will be made here, except to table two points. First, all three accredit high levels of activism to interpretive agents embedded in institutions of power. Second, they position Japan in interactive relationships with regional forces and processes. Taking both points into a discussion of the modern constitution of inter-civilisational engagement, it is proposed that Japan's particularly intense encounters with the West in the nineteenth century included an unusual and distinctive process of creation of a 'discourse of civilisations' (Duara, 2001). A significant confrontation with existing Western concepts of 'civilisations' was not only an encounter with a civilisational other; it was also the culmination of a longer history of engagement, especially in East Asia. Aspects of Japan's historical experience informed the wide-ranging confrontation with the global order and with Western empires in particular. Engagement with the West stimulated Japanese development of its own early discourse of civilisations. The remainder of the chapter elaborates on how this occurred.

The next section explores Japan's discourse of civilisation in depth. Examination of the modern Japanese figuration encompasses several thinkers and a particularly engaging environment of interpretation in Meiji-era Japan (1868-1912). The selection of intellectuals is based on how their key insights are stimulated by inter-civilisational engagement and how they are significant figures in cultural and political interpretations of modernity. In other words, the figures in question made significant contributions to the discourse of civilisations through creative borrowing, synthesis and fresh interpretations. 


\section{The discourse of civilisation in Meiji Japan}

The historical engagement with China ruptured suddenly, with the momentous encounters with the West. The dramatic consequence was a multifaceted transformation of state structures, politics, culture and economy. Worldwide cultural exploration of many other countries, along with an outgrowth of trade, stimulated an overhaul of the conceptual apparatus of Japan's political culture. The transformation involved the trans-cultural comprehension and deep consideration of foreign social, economic and political concepts. Debates about new concepts ensued and in turn problematised widely accepted traditions.

In a short time, the Meiji intelligentsia embarked on the creation of an early discourse of civilisations. Comprehension of foreign ideas about civilisation took place in public debates on the contents of what was believed to be a civilised mode of being. They fuelled a coalescing discourse of civilisations that incorporated impressions of Asian and East Asian civilisations (Duara, 2001; Mazlish, 2004). Western modernity seemed to the Japanese to be the embodiment of 'civilisation' as a mode of being juxtaposed to the moral value attributed to the religious heritage of Asian civilisations (Gluck, 2011). In the early years, 'being civilised' meant superficially following Western etiquette, fashions and speech. Many Japanese came to believe that the deeper attributes of Western modernities could be carefully modified. Encounters with the conceptual apparatus of Western thought encouraged this understanding. As with other concepts that entered East Asia in wider confrontation with Western colonialism (such as 'society', 'liberty', 'people', 'rights' and 'equality'), 'civilisation' was subject to intercultural appropriation and reconstruction during this period.

A particularly interpretive part of the Meiji-era transformation was careful observation of the world. Japan's intelligentsia was well equipped with existing learning processes, as it had for years deliberated on secularised neo-Confucian principles of knowledge (Collins, 2000: 685-6). Universities quickly sprang up with official support and patronage, once the German ideal of university education was discovered. The strong interest in philosophy is likely to have been accentuated by German universities acting as the inspiration (Collins, 2000: 371-2). Building on pre-Meiji traditions of school and academy education, they also had other pedagogical models to work with, which helped contend with new Western philosophies of utilitarianism and materialism. An additional experience of collective learning was the extraordinary Iwakura Mission (1871-73). Much of the intelligentsia learned from the hundreds who toured so many countries of the world in such a short time, learning about numerous national cultures. 
A many-sided inter-civilisational encounter resulted. Nearly four hundred days of travel brought extraordinary cultural learning in the physical and social sciences and humanities. The mode of comprehension of the sciences, economics, philosophies and political theories enabled Japan's leading intellectual-officials to recalibrate how knowledge was acquired and how it should be acquired in future. An accommodating and responsive civilisational pattern was activated to quickly acquire and recompose foreign theories, epistemologies and methodologies.

Knowledge and learning would only reach more deeply into society if a new public could be created. The new regime set about a partial democratisation of the polity and an overhaul of the centuries-old status hierarchy of four estates (known as shi-no-ko-sho). Beginning with the Charter Oath of 1868, levelling reforms flattened out the previous order. The five articles of the Charter Oath were civilisational goals for the restructuring of public life. During the 1870s, the common reading public grew rapidly, especially around newspaper readership.

As part of the urban public, the Meiji Six Society (Meirokusha) formed as an intellectual circle with its own activities and profile. Many of its young members also held government posts. Through its publications and public lectures, the Society acted as an agent of translation and conceptualisation of the Western sciences, as well as a debating society. In doing so the Meirokusha formed a benchmark of debate for a wider spectrum of opinion on Japanese civilisation and modernity. Working at the interstices of Japanese historical experience and Western ideas, members of the Meirokusha engaged in an interpretive role of 'description of a received world and construction of a new one' (Howland, 2002: 5). Many of the essays in its journal, Meiroku Zasshi, were critical of Japanese values, without at the same time being slavishly pro-Western. The Meirokusha were part of a vanguard fostering cultural criticism as part of the cognitive complex. They did not simply receive Western ideas in isolation from the Western origins of those ideas. Instead, the particular conditions of the Meiji upheaval were also a reference point for interpretation of new sociological and philosophical theories by members of the Meiji Six Society, particularly in the works of Kato Hiroyuki (1836-1916), Nakamura Keiu (1832-91), Nishi Amane (1829-97) and Tsuda Mamichi (1829-1903). A heavy emphasis on the properties of civilisation flowed through their writings, speeches, translations and newspaper articles (Braisted, 1976). They and others contributed to a limited, but coalescing, urban public in which the entire mode of public, urban debate was new. Through the medium of deliberative debate, the Meiji Six Society relativised Japanese traditions and Western knowledge both at once. The consequence of the Meirokusha's activities and publications was to promote debate about the direction of Japanese civilisation. Members held differing views about international law, constitutionalism and state formation, civil law and political sovereignty, the matter of 
rights and representation and modern subjectivity. All these were controversies synonymous with 'civilisation' and 'modernity' and part of early attempts to translate and evaluate the conceptual universe of Western knowledge (Mazlish, 2004: 100-3).

The published debates of the Meirokusha affirmed that development of 'civilisation' went beyond the engineering and infrastructural feats of the Meiji regime, beyond its trains, manufactories and street lights. The zeitgeist of the early Meiji years was bunmei kaika or 'civilisation and enlightenment'. Often misunderstood as mere exuberance for Western ways, bunmei kaika signified a larger ideal of modernisation oriented to both national upheaval and to the international environment. For the insiders of early Meiji governments, it looked like a strategy for a state without the capacities of other modernising states at this time. The strategy included restructuring the subjectivity of the Japanese in daily life and in civic obligation (Karlin, 2014). Bunmei kaika in daily life implied a containment and othering of provincial folk knowledge through the introduction of bureaucratic rationalities into the methods of government and propagation of an attitude to the past in popular sentiment. In this sense, bunmei kaika contrasted the existing regional worlds of early Meiji Japan with a modern polity and began the work of fostering a nationalist imaginary by articulating provincial identities with national loyalties in the name of 'civilisation'. At the same time, those regional worlds produced their own varied theories of modernity and democracy in the village-based Popular Rights Movement, which mobilised with considerable force in the 1870 s and the early 1880 s.

Bunmei kaika was also the leitmotif of the Meirokusha. For its members, 'civilisation and enlightenment' accentuated the gap between government ambitions to modernise the economy, rationalise jurisprudence and refine cultural customs and the state of popular consciousness and practice. The raison d'être of the Meiji Six Society therefore became a great deliberation on the character and content of the notion of 'civilisation' and how that gap might be closed. Its members translated and debated the works of the Western sciences for a large literate public with an appetite for foreign ideas and a desire to comprehend enigmatic foreign conceptions. As Fukuzawa noted in his reflections on the Iwakura Mission, even the travelling Japanese leaders on the mission expressed incredulity at the customs and practices of Westerners: 'On our part there were many confusing and embarrassing moments ... for we were quite ignorant of the customs and habits of American life ... Things social, political, and economic proved most inexplicable' (2005: 659).

Much of the scholarship of the Meiji Six Society touches on the perplexity of foreign concepts and how to express them. The idea of civilisation was an object in search of a signifier at this time of doubt. At different times 'civilisation' was 
termed kaikabunmei, keimei and bunka. Translation of the term was foregrounded as a problem in the Society's first issue of Meiroku Zasshi. In his provocative essay on Western languages Nishi Amane proposed shibirizeshon as a foreign loan word for 'civilisation' (Howland, 2002: 46-8). The most drastic pro-Western reform was wholesale adoption of the alphabet, according to Nishi: 'If we adopt their system, all things of Europe will be entirely ours. Since grasping this strong point of theirs while destroying our current writing system is not to be compared with a trivial change in clothing, we can boast to the world that it is the beauty of our people's character thus to follow the good' (Braisted, 1976: 9). Letters themselves in their elegant and tidy simplicity represented a condensation of Western thinking. Therefore, shibirizeshon would stand in well for 'civilisation', so Nishi Amane argued. Debate ensued but the overall proposition was too threatening to a sense of Japanese collectivity. As his propositions received little support, the idea of direct translation was soon abandoned altogether.

Instead, Fukuzawa's work was the means by which bunmei kaika became the most common term. As a linguistic sign, it had hard work to do. Bunmei kaika condensed two conceptions of civilisation into a single phrase (Howland, 2002: 32-43). The two conceptions were the strong noun bunmei for 'civilisation' in the sense of universal civilisation and kaika for the process of cultivating a civilised subjectivity. In this shape bunmei kaika represented a broad-spectrum discourse on the nature of being civilised. In cross-cultural engagement with the West, the outward appearance of 'civilised' behaviour would signal conformity with expectations of behaviour common to Western elites by this time. Members of the Meiji elite understood civility as a gendered exteriorisation of refinement, manners, etiquette and customs (Karlin, 2014). 'Good' comportment reflected well on Japan and the Japanese could impress foreigners with a mannered subjectivity. 'Civilisation' was thus an outward expression of a mode of behaviour.

The phrase was elastic in other ways. The semantics of civilisation could serve a variety of political perspectives on the social order. The Popular Rights Movement imagined a more radical constitutional and societal order and expressed that imagination in a language of democracy. It was an independent movement of forces-from-below with an unprecedented vision of restructuring social life (Bellah, 2003: 167-70). In a backlash against the free thinking of some of the experiments associated with bunmei kaika, Meiji conservatives also spoke a language of civilisations. Moderate conservatives engaged by asserting that the distinctive Japanese character had to be preserved throughout the more general transformation. Traditionalists went further, maintaining an outright xenophobic rejection of foreign influences. Yet even the arguments of the most ardent 
cultural nationalists were enveloped in the new discourse that underlay public debates.

Fukuzawa was a lightning rod for public debate about civilisation. Hundreds of thousands read his major works of public opinion. His interpretation of bunmei kaika in An Encouragement of Learning was a leading opinion read by millions of Japanese. Fukuzawa's opinion was the most especial vision of the civilisational order of this era. China had been the major inspiration to purposeful transformation in the past. Engagement with the West connected Japan to a larger world, however, and China lost its place, according to Fukuzawa. His use of bunmei kaika semantically shifted the term's connotation from the Chinese order and system of moral education familiar to the Japanese to a larger international one (Howland, 2002: 33-8, 50-60). In the process, kaika stood in for cultivation of civilised subjectivity amongst the emperor's subjects, which implied an 'openness' of outlook juxtaposed to the national closure associated with the sakoku policy of the preceding Tokugawa era (Karlin, 2014: 138-9). In Fukuzawa's eyes, all this resulted from the great encounter in which the West's 'unknown culture was to be met and to be closely associated with' (Fukuzawa, 1985: 102), including at the level of the behaviour of the Emperor's officials and subjects. Fukuzawa went further when he fastened Japan's development to the strategy of learning from the West, but then projected it beyond the particular modernity of Western civilisation: 'civilisation is an open-ended process. We cannot be satisfied with the present level of attainment of the West' (2005: 701).

He also spoke of 'civilisation' in the singular as a spirit of independence. Fukuzawa's phrase yo no bunmeikaika can be rendered as 'world civilisation', an expression of the universality that complements the acquisition of 'things Western' (Howland, 2002: 34). In An Encouragement of Learning Fukuzawa depicts his 'spirit' of civilisation as the independent pursuit of knowledge (Fukuzawa, 1985: 93-100). Japan lacked the independence of spirit that Fukuzawa believes to be indispensable for civilised subjectivity. Mere acquisition of technology is insufficient. The value of civilisation lies in a practised inquisitiveness. Progress cannot be indexed by the accumulation of material appurtenances alone, but by the popular exercise of independence of mind. For Fukuzawa, this was a matter of the kind of society that modern Japan would produce. He believed in principles of meritocracy, but articulated these in the context of national integration (Bellah, 2003: 167). At the beginning of Outline of Civilisation, he states that a 'discourse on civilisation is a discourse on the development of the human. It does not deal with the development of the mind of an individual but the minds of people as a group in the whole of society' (Fukuzawa, 1985: 101). Fukuzawa hoped to create coherence around the larger group identity using the language of civilisation, society and nation. Through such a connection the Japanese people 
could identify with an abstract and unfamiliar ideal, while at the same time also identifying with the sovereign body of the Emperor.

Fukuzawa was an exceptional figure in promoting the discourse of civilisations. His published opinions reflected the general debates of the Meirokusha. That the phrase had currency in the Meiji Six Society by early 1875 is confirmed in Nishimura Shigeki's 'An Explanation of Twelve Western Words' . Nishimura presented a lexicology of 'civilisation' in this essay. He found that the term had a double connotation in European languages. On one hand, as a noun it connoted the ensemble of economic and cultural institutions. On the other hand, it signified a tempering subjectivity. The double entendre is captured in a reading of Guizot and Mill that is reminiscent of Fukuzawa:

In the view of these two scholars, civilization's form appears on two paths: one is through group relations and the other is through the conduct of man [sic] as an individual ... We cannot speak of civilization unless there is a parallel advance in the dignity of social intercourse as a whole and man [sic] as an individual. Even though the nation as a whole moves towards prosperity, when the wisdom of the people has not advanced in the least, their prosperity is not to be trusted as its source is extremely unclear. Thus, although civilization applies to social intercourse as a whole, as well as to man $[s i c]$ as an individual, its essence, being the elevation of individual dignity, extends by inference to the whole of social intercourse. (Braisted, 1976: 447)

According to Nishimura, acquisition of the virtues of civilised subjectivity should be pre-eminent, the sine qua non of civilisation if you will. The complexity of civilisation that Fukuzawa constructs is echoed here. Evolutionist tones are unmistakable, though Nishimura also acknowledges that the apex of civilisation has shifted frequently throughout global history: 'the areas that have advanced civilisation after achieving prosperity at a particular time were Africa in ancient times, then Asia, and now similarly Europe' (Braisted, 1976: 449). Civilisation is not always European for all places at all times, a conclusion also reached by Fukuzawa.

The commitment to international knowledge by the Meiji elite had oriented the Japanese to an outside universality and situated their society in an international order that included a normative standard of civilisation (Gong, 1984: 164-200). Suggestions that early Meiji Japan merely mirrored the West in development of imperialist missions are not especially convincing. However, there is little doubt that awareness of the greater outside world increased substantially in the early Meiji years and it could not but incorporate Western exemplars of imperialism. That was part of inter-civilisational engagement. Greater awareness of international relations also increased the anger about the secondary place in the world 
order accorded to Japan by Western powers. Many Japanese believed that their civilisation deserved to be treated as an equal. They saw in the normative principles of the international order a justification for their advancement. But Japan's place did not formally alter until after the reversal of the unequal treaties in 1905. Arguably it did not alter much after 1905 either, even though the standard of civilisation continued to reign in the international arena.

Meanwhile Japan's own reckoning of the world had already been irreversibly enlarged. Other civilisations and cultures came into view. Most importantly, the place of Asia and China in the international arena was re-envisaged in which Western states were increasing in imperial power and influence. Governments in the late Meiji era believed that Japan ought to be treated on a par with Western states. A more assertive outlook translated in part into wars with China and Russia and the early stirrings of Japanese colonialism. In this climate, the term bunka as 'culture' began to acquire prominence alongside bunmei (Howland, 2002: 37-8). Like the German distinction of particularising Kultur juxtaposed to the universalist notion of civilisation promoted by the French, the ascendancy of bunka accorded with Japanese nationalism. Unlike the German notion, the Japanese ideal of bunka came to the fore in an environment in which images of civilisation were derived from an international arena dominated by the Western powers.

\section{Late Meiji: civilisation contested}

New perspectives emerged after linguistic consolidation of a discourse of civilisations and after the heightening of consciousness around the standard of civilisation. In the 1890s, Meiji leaders could point to signs of progress in the foundation of a constitutional polity and the early stages of industrialisation. Japan's impact on the international arena also deepened in the wake of military victories over China and Russia. While the West did not fade from Japan's field of vision, Asia was enlarged in strategic considerations. Four perspectives formulated against the backdrop of the two military adventures cast Japanese modernity in a context of shifting balances of international power. Tokutomi Soho, Okakura Tenshin, the scholars of orientalist toyoshi sciences and the Christian pacifist Uchimura Kanzo all circulated different reactions to the new relationship with the world order and particularly with Asia. Experience of international travel and engagement with foreign currents of thought informed this new intelligentsia, which otherwise disagreed on questions of how Japan as a civilisation should relate to the world.

Tokutomi Soho was a youthful participant in the 1880s Popular Rights Movement who emerged as a widely read and admired intellectual. He had a 
sophisticated grasp of influential Western and Japanese thinkers and blended a classical Japanese education with familiarity with Guizot, Macauley, Mill, Spencer and Tocqueville. After his early involvement with liberalism he quickly found a Spencerian voice. In his account of Japan's state in the mid-1880s (Tokutomi, 1989), he positions Japan's fragile modernity on a civilisational path from militant to commercial-industrial society. Tokutomi iterated a disdain for the feudal burden of the past. Style, appearance and refinement were expressions of society in a modernising phase, as far as he was concerned. The backdrop to his sociology was a gendered performance of civilisation (Karlin, 2014). Older manners, clothes and customs gave way to new etiquette, fashion and popular cultures. The new civilities were contested but still moved as part of the shift from militarism to commerce that Tokutomi advocated and described. The measures implemented in the early Meiji years had to go further and reach more deeply into society, if democratisation were to be realised. In a more contingent vein, Tokutomi imagines Japan's prospects as shaped by colliding social forces (1989: 20-1, 167-82). Several scenarios were possible for Japan as domestic conservatism stood in contradiction with compelling international impulses. Furthermore, within Japan itself military and economic logics competed with each other and the outcome looked unclear. So Tokutomi's sociology was not merely a replica of Spencerian evolutionism, but a more ambivalent account of a developmental pattern contingent on unpredictable contradictions. Optimistic about the future, but alert to its pitfalls, Tokutomi was sincerely hopeful for a commercial-industrial and peaceful democratic country, but uncertain whether it would emerge or not. In this respect, his perspective on the order of civilisations gave him more of a sensibility about Japan's historically specific development than Spencer allowed for. As time went on, however, Tokutomi's vision of civilisation turned to a soft nationalism, which then steadily hardened as militarism arose.

Two Asia-oriented instantiations of the discourse of civilisations are too important to ignore in light of subsequent developments. Okakura Tenshin's Pan-Asian perspective was solidarity-oriented and affirmed nascent nationalisms in Asia that were emerging in reaction to the double standard of the international standard of civilisation. There was another Asia-oriented intervention in the form of toyoshi (Oriental) studies that pictured Japan in the lead. Romanticising a 'lost' ecumenical Asian past, Okakura sees in Japan's modernity an overall negotiation with the West's civilisation on Japan's terms (2006 [1904]). In contrast, other great powers in Asia have either succumbed to Western colonialism or been forcefully subordinated by it. Okakura's catalogue of the contributions of different Asian civilisations to the cultural vitality aggregated in independent modern Japan seems not to have implied a closed Orientalism. If Okakura's 1904 tract, The Awakening of Japan, was easily given to later ultra-nationalist reception, then 
it was also pliable to other points of view. The most remarkable example of his Pan-Asianism was his inter-cultural dialogues with anti-colonialist Rabindranath Tagore. Through his relationship with Tagore, he helped craft a moderate Asiaoriented world view grounded in the agreed common ground of Asian cultures (Bharucha, 2006; Dirlik, 1997: 113-14). By the time he came to consider 'civilisation' in those dialogues, it seemed the discourse of civilisations dealt with a datum of assumed common sense, and not the indefinitely problematised notion that 'civilisation' was for his interlocutor Tagore (Bharucha, 2006: 76-83). As the cries of nationalism increased, Okakura went silent on Asia's relationship with Japan. By way of contrast, Tagore's stance became more significant in India as anti-colonialist nationalism became more compelling. A second Asia-oriented position edged out this first inter-cultural perspective.

The orientalist history that laid quasi-scientific grounds for militarist orientations to Asia was toyoshi studies. A brief summary cannot do justice to the disciplinary breadth of Japanese orientalism, but a few pointers are pertinent. Toyoshi studies coalesced in the 1890 s with abandonment of the Enlightenment enthusiasm of the early Meiji period (Tanaka, 1993). This stridently nationalist school of cultural Asianism evolved alongside Okakura's inter-cultural articulation of Asian solidarities, but was also a rival vision. The past-oriented Romanticism of Okakura had no place in toyoshi histories with its positivist mood. Deterred by the cultural and historical specificity of the Western social sciences, toyoshi turned away from universalism. Toyoshi scholars embraced an Asian particularism in its place, which situated Japan at Asia's head as representative of its treasures. Civilisation was still the premier condition, and Japan represented the apparent ways-of-civilisation for Asia. Carol Gluck's summary (1985: 253-7) of the process of adoption and 'naturalization' of bunmei by the time toyoshi studies started to emerge is apt: " civilisation" appeared as an indigenous fact of social life that possessed the same descriptive transparency as any unmodified common noun' (1985: 254). The theories of civilisation spanning the range of Asianist perspectives may have varied. However, they all built on the apparatus of concepts and sciences constructed in the early Meiji period and thus could take a place in the more fulsome discourse of civilisations that Duara points to.

Concerns over the 'progress' of Japanese civilisation that circulated in the public writings of Tokutomi were shared by the author of the next perspective heterodox Protestant Uchimura Kanzo. Some comparison of the two can help clarify the power of Uchimura's point of view. Both had negative experiences of life in the United States and were focused on trans-Pacific relations. Japan's seizure of Taiwan and Korea and the annexation of Samoa, Guam and the Philippines by the United States enlarged the importance of the Pacific for the Japanese (see Matsuda, 2012: 243-5). But Tokutomi and Uchimura each drew different 
conclusions. Tokutomi steadily became more nationalist, whereas Uchimura steadily became more alarmed about the military consequences of the regime's self-understanding of civilisation. Tokutomi's earlier optimism had given way to bitterness about the deep misunderstandings in relations with the United States. Premonitions of the deterioration in relations during the late Meiji era turned into full-blown warnings in the Taisho years (Tokutomi, 1922). Tokutomi's fear of an extension of the Monroe Doctrine to the Pacific drove him to a more stridently nationalist position. His fear was nourished by the United States' antiJapanese immigration policies. The alarm about the United States rang out differently in Uchimura's projections of Japan's destiny. Uchimura couches his fears in the language of 'civilisations': 'What is Japan's mission, or what can she do for the world? If Egypt and Babylon started civilisation, Phoenicia dispersed it, Judea purified it, Greece polished it, Italy preserved it, Germany reformed it, England tempered it, and America executed it, is nothing more left for Japan to work on?' (cited in Lee, 1981: 89). He is disappointed that history has left nothing for Japan to do. Like Tokutomi, Uchimura also felt disappointment with the United States. He had invested high hopes and saw the United States as an ideal of modernity. His ultra-Protestantism and pacifist ethics set him apart from Tokutomi, however. A well-informed figure on Japan-US relations, he was well placed to compare the styles of life of both societies. His bitter memories of studying in the United States refined his understanding of a Japanese subjectivity. For Uchimura, only an independence of mind would give Japanese Christians the autonomous congregational and social life that he thought they needed. If Japanese Christians could attain a spirit of independence they would exemplify modern civilisation and, incidentally, resist the pressures to conform that mounted in the late 1920s (Bellah, 2003: 44). With his 'non-church movement' (mukyokai), Uchimura organised a non-sectarian home for dissenting Christians, a 'dormitory for those who have no home, the orphanage or foundling home for the spirit' (Uchimura, 1958: 347). His heterodox Protestantism brought him public scandal and marginalised him along with a growing number of socialists and pacifists. While he was ambiguous about socialism, and saw a developmental role for private enterprise in society, his pacifism was unshakable.

He and his associate dissenters in the mukyokai acted as a clearing house of religious, moral, sociological and political ideas taken from an image of US modernity, from developments in unfolding American-Japanese relations and from experiences of life in the United States. With these, Uchimura developed a sui generis pacifist Japanism. His version of 'Japanese Christianity' was a blend of Western influences with the valued moral traditions of Japan (Howes, 2006). From the West he freely took tenets of Christianity, while refusing to be dominated by missionary agencies. With this cross-civilisational fusion, Uchimura 
sought to balance two equations: one of patriotism and an ethic of independence, and the other of Western Christianity and the core moral traditions of Confucianism and Buddhism. Bellah fairly describes this as an 'ethical individualism' (2003: 103-7). With a blended Japanism, he stood with socialists and Okakura in opposition to the nationalist version of civilisation envisaged by the regime. There were a few exceptional socialists who, alongside Okakura and Uchimura, spoke out against Japanese expansion. Their perspectives would be interesting too, but cannot be explored here.

\section{Conclusion}

East Asia's discourse of civilisations had its origins in Japan in the 1870s. The Japanese found themselves reorienting to a largely unfamiliar Western political, cultural, economic and cognitive complex. They grappled with new and unfamiliar ideas, with translation being a point of first deep contact in what would turn out to be a longer cultural and political engagement. The 'Japanisation' of the human sciences and its conceptual apparatus came about via a particular struggle around conceptions of civilisation, society and modernity. Different terms to express new conceptions emerged from this exceptionally intense phase of inter-civilisational engagement, which can be reckoned as encounters. Deliberation over a number of perceived elements of civilisations in the Meirokusha gave way to versions of civilisation oriented to the Asian region and to the United States. The discourse of civilisations obtained an Asian-oriented form in the early twentieth century encompassing four competing perspectives on relations between Japan, Asia and the West in the late-Meiji-Taisho eras. The denial of equal status with the West generated tensions on the international front, which contextualised all four. With the ascendency of militarism, the most contestatory visions of civilisation faded. But the discourse of civilisations posited by Duara as a development of the 1920s and 1930s did not.

Japan embarked on an inter-civilisational encounter on a large scale at the outset of this period. However, the encounter both based itself on historical experiences of engagement with East Asia and broke new ground in engaging a larger international arena of empires and civilisations. Japan's orientation were northern to Russia, western to Europe and Asia, southern to Australia and, most importantly, trans-Pacific. New landscapes of cultural and political engagement emerged, which I have focused on in this chapter. By extending the model of interaction laid down in the major studies of Japan in contemporary civilisational analysis, I have linked inter-civilisational encounters and engagement in a very 
particular context. As well as an enlargement of the range of inter-civilisational engagement in political and cultural perspectives, there was a widening of economic relations and emigration as well. How that transpired is beyond this chapter (but see Smith, 2014c).

This chapter completes the in-depth studies of Part II. I have fathomed particular examples of inter-civilisational engagement. My survey includes oceanic civilisations, the Oceanian civilisation, Latin American movements of political and cultural engagements and, finally, Japan's exceptional encounter with the West and instances of political and cultural engagement that ensued. I have examined, to varying degrees in all cases, the four dimensions of intercivilisational engagement to support my critical synthesis of the illuminating insights of civilisational analysis. I am stressing the relational character of civilisational formations, howsoever they may be construed. Immediately, the question is posed, again, of the conception of civilisation and civilisations at work in the field and, indeed, in the perspective unpacked in these pages. In the Conclusion, I return to conceptual problems and some other important questions of the human condition. 